\title{
Incorporating oral health care education in undergraduate nursing curricula - a systematic review
}

\author{
Vandana Bhagat ${ }^{*}$ (D), Ha Hoang ${ }^{2}$ (D) Leonard A. Crocombe ${ }^{3}$ (D) and Lynette R. Goldberg ${ }^{4}$ (D)
}

\begin{abstract}
Background: The recognised relationship between oral health and general health, the rapidly increasing older population worldwide, and changes in the type of oral health care older people require have raised concerns for policymakers and health professionals. Nurses play a leading role in holistic and interprofessional care that supports health and ageing. It is essential to understand their preparation for providing oral health care.

Objective: To synthesise the evidence on nursing students' attitudes towards, and knowledge of, oral healthcare, with a view to determining whether oral health education should be incorporated in nursing education.

Methods: Data sources: Three electronic databases - PubMed, Scopus, and CINAHL. Study eligibility criteria, participants and interventions: Original studies addressing the research objective, written in English, published between 2008 and 2019, including students and educators in undergraduate nursing programs as participants, and conducted in Organisation of Economic Co-operation and Development countries. Study appraisal and synthesis methods: Data extracted from identified studies were thematically analysed, and quality assessment was done using the Mixed Methods Appraisal Tool.
\end{abstract}

Results: From a pool of 567 articles, 11 met the eligibility criteria. Findings documented five important themes: 1 .) nursing students' limited oral health knowledge; 2.) their varying attitudes towards providing oral health care; 3.) the need for further oral health education in nursing curricula; 4.) available learning resources to promote oral health; and 5.) the value of an interprofessional education approach to promote oral health care in nursing programs.

Limitations: The identified studies recruited small samples, used self-report questionnaires and were conducted primarily in the United States.

Conclusions: The adoption of an interprofessional education approach with a focus on providing effective oral health care, particularly for older people, needs to be integrated into regular nursing education, and practice. This may increase the interest and skills of nursing students in providing oral health care. However, more rigorous studies are required to confirm this. Nursing graduates skilled in providing oral health care and interprofessional practice have the potential to improve the oral and general health of older people.

Keywords: Oral health, Oral care, Older people, Nursing, Attitudes, Education, Understanding, Knowledge, Curricula, Interprofessional

\footnotetext{
* Correspondence: Vandana.Bhagat@utas.edu.au

${ }^{1}$ Centre for Rural Health (CRH), E Block, Newnham Campus, University of

Tasmania (UTas), Launceston, Australia

Full list of author information is available at the end of the article
}

\section{$\triangle B M C$}

(c) The Author(s). 2020 Open Access This article is licensed under a Creative Commons Attribution 4.0 International License, which permits use, sharing, adaptation, distribution and reproduction in any medium or format, as long as you give appropriate credit to the original author(s) and the source, provide a link to the Creative Commons licence, and indicate if changes were made. The images or other third party material in this article are included in the article's Creative Commons licence, unless indicated otherwise in a credit line to the material. If material is not included in the article's Creative Commons licence and your intended use is not permitted by statutory regulation or exceeds the permitted use, you will need to obtain permission directly from the copyright holder. To view a copy of this licence, visit http://creativecommons.org/licenses/by/4.0/ The Creative Commons Public Domain Dedication waiver (http://creativecommons.org/publicdomain/zero/1.0/) applies to the data made available in this article, unless otherwise stated in a credit line to the data. 


\section{Introduction \\ Rationale}

Oral health is measured by the absence of orofacial pain, oral infection, periodontal (gum) diseases, tooth decay, tooth loss, and other orofacial diseases and disorders that can affect a person's overall physical and mental health, and social well-being [1-3]. This is a particular concern for older people [2-5]. The world's population is ageing rapidly [4]. Living longer brings challenges when meeting the complex healthcare needs of many older people and ensuring their quality of life. Currently, there is a profound disparity in the oral health of the older population, even in high-income countries [5].

Worldwide, the oral health of older people, defined as those over 65 years of age, is poor with a high prevalence of dental caries, periodontal diseases, dry mouth problems, and incremental tooth loss [5, 6]. Oral health problems often lead to malnutrition, and difficulty with speech and swallowing [7]. There is increasing evidence of the association of periodontal problems with systemic conditions including type II diabetes, osteoporosis, cardiovascular problems such as myocardial infarction, stroke, coronary heart disease, and aspiration pneumonia that may lead to unplanned hospitalisations [8-10]. Poor oral health impacts morbidity, mortality, and recovery time after treatment $[11,12]$. Pain and suffering resulting from oral health problems may influence older people's mood and behaviour, particularly if they have difficulty in communicating their discomfort [13]. Poor dental appearance and bad breath can lower self-esteem and exacerbate social isolation [14]. Thus, oral health problems can have profound physical, psychological, social, and economic consequences.

Most oral health problems experienced by older people are preventable or treatable [15]. However, they remain underdiagnosed and untreated due to the lack of effective, efficient, and equitable distribution of oral health services [15]. Reasons for the inadequate delivery of oral health services to older people include limited resources, poor understanding of oral care among nursing staff, lack of interprofessional collaboration, and inadequate policy protocols $[16,17]$. The lack of time, competing priorities, a high workload, and staffing issues are also significant barriers for providing oral care to older people [18].

The provision of quality and timely oral health care services to the rapidly increasing older population has become a large challenge for policymakers and health professionals $[9,19,20]$. Many changes have occurred in the oral health care needs of the older population in the twenty-first century due to the preservation of natural teeth, and the placement of complex prostheses such as crowns, bridges, overdentures, and implants. These changes highlight the need for staff trained in providing oral health care to older people [21, 22]. With increasing age and ill-health, many people need assistance with their oral and general health care [23, 24]. This is particularly true for dependent older adults in residential care communities and hospitals. However, oral health care is a low priority for non-dental health professionals [6, 25-27].

Interprofessional education and collaborative practice have been recognised as a valuable approach to alleviate the global health workforce crisis and prepare a health workforce that will better respond to local health needs and ensure safe, holistic practice [28]. The World Dental Federation (FDI) also supports the need for interprofessional education and collaborative practice to improve access to oral health services [29]. Involving nurses, primary health care workers, and other allied health professionals in oral health care, will increase the national capacity to reach vulnerable and underserved population groups, including older people [6]. Nurses account for a large proportion of the health care workforce and are often present at the point of care or supervising direct caregivers [30, 31]. Therefore, oral health care education and training are essential for graduating nurses to improve the oral and systemic health of older people [32-36]. Such education and practice provided with an interprofessional approach enables nursing students to contribute, learn and work effectively with other professionals involved in oral health [29].

Nurses provide care to older people in various settings such as hospitals, residential aged care, rehabilitation units, as well as in the community. Community nurses can educate and empower older people to take an active role in their oral care to prevent oral problems [37]. Nurses working in residential communities can take a leadership role in ensuring oral health care is integrated into routine nursing care [38]. Nurses can screen each resident's oral health upon admission, assess the need for an examination by a dental professional, and prepare and monitor an oral health care plan [25, 39, 40]. Registered nurses can train and supervise personal care assistants in providing support to residents to maintain oral hygiene, monitor adequate nutrition, and identify signs of oral diseases [33]. Similarly, in hospitals, nurses can promote oral health, screen for any suspicious oral pathology, and make appropriate referrals [41]. Given interprofessional support, nurses can improve and maintain the oral health of older people when immediate access to an oral health therapist is not available [23].

\section{Objective}

To synthesise the evidence on nursing students' attitudes towards, and knowledge of, oral health care, with a view to determining whether oral health education should be incorporated in nursing education. To our best knowledge, no previous study has summarised the literature on this topic. 


\section{Research questions}

1. What do nursing students understand about oral health care?

2. What are the attitudes of nursing students towards providing oral health care?

3. Is there evidence of oral health education and training in nursing curricula?

\section{Methods}

A systematic review was performed following Preferred Reporting Items for Systematic Reviews and MetaAnalyses (PRISMA) guidelines [42].

\section{Eligibility criteria}

Original studies addressing the research questions, written in English, published between 2008 and 2019, including students and educators in undergraduate nursing programs as participants, and conducted in Organisation of Economic Co-operation and Development (OECD) countries. The review excluded studies involving students from certificate nursing courses, graduate nursing programs, and midwives. Studies reported in conference proceedings, short communications, thesis, or book chapters were also excluded.

\section{Information sources and search}

Three electronic databases were searched: PubMed, Scopus, and CINAHL. Boolean operators with the following keywords and strategy were used: (oral care OR dental health OR oral health OR dental care OR mouth care OR oral hygiene) AND (nursing students OR nurse students OR nurse undergraduates $\mathrm{OR}$ nurse educators) AND (curriculum OR curricula OR knowledge OR understanding OR learning OR teaching OR attitudes OR interprofessional education OR interdisciplinary education). A detailed example of the search strategy used for Scopus is outlined (Fig. 1). This search strategy was adapted for each of the databases.

\section{Study selection}

All original studies, including quantitative, qualitative, and mixed-method studies, were selected if they met the eligibility criteria. After an initial search and removing duplicates from the search list, titles and abstracts were independently screened by two authors $(\mathrm{VB}, \mathrm{HH})$ and the full texts of identified papers were then sought. Studies not fitting the eligibility criteria were excluded before the full text was reviewed. In cases of disagreement, two additional authors (LC, LG) were consulted to resolve any conflicts. Disagreements were resolved with consensus by referring back to the protocol. Research data were synthesised systematically, and the quality of the included studies was then evaluated.

\section{Data extraction}

The data collection form was developed by two authors (VB, $\mathrm{HH}$ ) referring to previous systematic reviews in the related field; data extraction was then performed independently by VB. The accuracy of the extracted data was verified by the second author $(\mathrm{HH})$. Information collected from the identified articles for this systematic review included: country and setting, details of participants, objectives of the study, research design, description of the main findings related to the three research questions, and the reported limitations of each study (Table 1).

$$
\begin{aligned}
& \text { Search: (ALL(oral care OR dental health OR oral health OR dental care OR mouth care OR oral hygiene)) } \\
& \text { AND (ALL(nursing students OR nurse students OR nurse undergraduates OR nurse educators)) AND } \\
& \text { (ALL(curriculum OR curricula OR knowledge OR understanding OR learning OR teaching OR } \\
& \text { attitudes OR interprofessional education OR interdisciplinary education)) AND ( LIMIT-TO ( } \\
& \text { PUBYEAR,2019) OR LIMIT-TO ( PUBYEAR,2018) OR LIMIT-TO ( PUBYEAR,2017) OR LIMIT-TO ( } \\
& \text { PUBYEAR,2016) OR LIMIT-TO ( PUBYEAR,2015) OR LIMIT-TO ( PUBYEAR,2014) OR LIMIT-TO ( } \\
& \text { PUBYEAR,2013) OR LIMIT-TO ( PUBYEAR,2012) OR LIMIT-TO ( PUBYEAR,2011) OR LIMIT-TO ( } \\
& \text { PUBYEAR,2010) OR LIMIT-TO ( PUBYEAR,2009) OR LIMIT-TO ( PUBYEAR,2008) ) AND ( } \\
& \text { LIMIT-TO ( LANGUAGE,"English" ) ) }
\end{aligned}
$$

Fig. 1 Full electronic search strategy 
Table 1 Characteristics of identified studies

\begin{tabular}{|c|c|c|c|c|c|c|}
\hline Reference & $\begin{array}{l}\text { Setting and } \\
\text { country }\end{array}$ & Objective & Participants & Research Design & Main findings & Limitations \\
\hline $\begin{array}{l}\text { Clemmens, } \\
\text { Rodriguez \& } \\
\text { Leef, } 2012 \text { [43] }\end{array}$ & $\begin{array}{l}\text { A large private } \\
\text { urban university, } \\
\text { USA }\end{array}$ & $\begin{array}{l}\text { To identify the } \\
\text { knowledge, attitudes, } \\
\text { and practices of } \\
\text { baccalaureate nursing } \\
\text { students regarding oral } \\
\text { health assessment. }\end{array}$ & $\begin{array}{l}\text { A convenience sample } \\
\text { of } 163 \text { baccalaureates } \\
\text { nursing students }\end{array}$ & $\begin{array}{l}\text { Descriptive } \\
\text { cross-sectional } \\
\text { survey }\end{array}$ & $\begin{array}{l}\text { Although nursing } \\
\text { students felt that oral } \\
\text { health is an essential } \\
\text { component in nursing } \\
\text { practice, they lacked a } \\
\text { complete understanding } \\
\text { of the critical } \\
\text { components of an oral } \\
\text { health examination and } \\
\text { promotion. Almost all } \\
\text { the participants (97\%) } \\
\text { believed that they had a } \\
\text { good understanding of } \\
\text { oral health assessment, } \\
\text { but only } 25 \% \text { were able } \\
\text { to recognise the } \\
\text { components of oral } \\
\text { health assessment. Less } \\
\text { than } 2 \% \text { reported } \\
\text { performing an oral } \\
\text { health assessment for } \\
\text { every patient. }\end{array}$ & $\begin{array}{l}\text { The validity and reliability } \\
\text { of the survey instrument } \\
\text { were not established on } \\
\text { the cohort of nurses. } \\
\text { Moreover, data collected } \\
\text { from a single university } \\
\text { so results cannot be } \\
\text { generalised. }\end{array}$ \\
\hline $\begin{array}{l}\text { Doğan, } \\
2013 \text { [44] }\end{array}$ & $\begin{array}{l}\text { Marama } \\
\text { University, } \\
\text { Turkey }\end{array}$ & $\begin{array}{l}\text { To assess the differences } \\
\text { in oral health behaviour } \\
\text { and attitudes between } \\
\text { nursing and dental } \\
\text { students. }\end{array}$ & $\begin{array}{l}157 \text { nursing students } \\
\text { and } 71 \text { dental students }\end{array}$ & $\begin{array}{l}\text { A comparative } \\
\text { descriptive } \\
\text { cross-sectional } \\
\text { survey }\end{array}$ & $\begin{array}{l}\text { The attitudes of dental } \\
\text { students to oral health } \\
\text { were significantly more } \\
\text { positive than that of } \\
\text { nursing students ( } p< \\
\text { 0.001). The proportion of } \\
\text { students avoiding } \\
\text { visiting a dentist until } \\
\text { they had a painful oral } \\
\text { condition was } \\
\text { significantly higher } \\
\text { among nursing students } \\
\text { than dental students. A } \\
\text { third (33\%) of nursing } \\
\text { students in comparison } \\
\text { to } 6 \% \text { of dental students } \\
\text { thought that they could } \\
\text { not avoid having false } \\
\text { teeth in old age. The } \\
\text { dentist found that dental } \\
\text { students (58\%) were } \\
\text { better at brushing in } \\
\text { comparison to nursing } \\
\text { students ( } 25 \% \text { ). The } \\
\text { variation in attitudes and } \\
\text { behaviour of nursing and } \\
\text { dental students reflected } \\
\text { the significance of } \\
\text { practical training and } \\
\text { curriculum. }\end{array}$ & $\begin{array}{l}\text { Data collected from } \\
\text { students of one } \\
\text { university only so results } \\
\text { cannot be generalised. }\end{array}$ \\
\hline $\begin{array}{l}\text { Haresaku et al., } \\
2018 \text { [45] }\end{array}$ & $\begin{array}{l}\text { Nursing, dental, } \\
\text { and dental } \\
\text { hygiene school } \\
\text { belonged to } \\
\text { school cooperation } \\
\text { in Fukuoka } \\
\text { Prefecture, Japan }\end{array}$ & $\begin{array}{l}\text { To identify the weak } \\
\text { points in knowledge, } \\
\text { attitudes, and factors } \\
\text { building positive } \\
\text { willingness to practice } \\
\text { oral health care among } \\
\text { nursing and oral } \\
\text { healthcare students. }\end{array}$ & $\begin{array}{l}\text { First-year nursing (119), } \\
\text { dental (88), and dental } \\
\text { hygiene students (64) }\end{array}$ & $\begin{array}{l}\text { Analytical cross- } \\
\text { sectional survey }\end{array}$ & $\begin{array}{l}\text { Nursing students had the } \\
\text { poorest knowledge and } \\
\text { attitudes towards oral } \\
\text { health care compared to } \\
\text { other student groups. } \\
\text { About } 40 \% \text { of nursing } \\
\text { students felt they did not } \\
\text { know much about oral } \\
\text { healthcare, and } 39.2 \% \\
\text { were not interested in } \\
\text { oral healthcare. Only half } \\
\text { of all students knew that } \\
\text { oral health care is } \\
\text { necessary to prevent } \\
\text { general health problems } \\
\text { like cardiovascular } \\
\text { disease and aspiration } \\
\text { pneumonia. } \\
\text { Acknowledging and } \\
\text { building interest among } \\
\text { nursing students about } \\
\text { oral healthcare is } \\
\text { associated with a }\end{array}$ & $\begin{array}{l}\text { Results collected from a } \\
\text { single nursing school, } \\
\text { so the attitudes and } \\
\text { behaviours cannot be } \\
\text { generalised. }\end{array}$ \\
\hline
\end{tabular}


Table 1 Characteristics of identified studies (Continued)

\begin{tabular}{|c|c|c|c|c|c|c|}
\hline Reference & $\begin{array}{l}\text { Setting and } \\
\text { country }\end{array}$ & Objective & Participants & Research Design & Main findings & Limitations \\
\hline & & & & & $\begin{array}{l}\text { positive willingness for } \\
\text { oral health practices. } \\
\text { Therefore, it is essential } \\
\text { to develop a } \\
\text { collaborative nursing oral } \\
\text { health curriculum to } \\
\text { motivate nursing } \\
\text { students. }\end{array}$ & \\
\hline $\begin{array}{l}\text { Pai, Ribot, } \\
\text { Tane, \& } \\
\text { Murray, } \\
2016[31]\end{array}$ & $\begin{array}{l}\text { Four Charles } \\
\text { Sturt University } \\
\text { campuses in } \\
\text { regional NSW, } \\
\text { Australia }\end{array}$ & $\begin{array}{l}\text { To assess final year } \\
\text { nursing students' } \\
\text { awareness of the } \\
\text { periodontal disease. }\end{array}$ & $\begin{array}{l}30 \text { final year nursing } \\
\text { students }\end{array}$ & $\begin{array}{l}\text { Cross-sectional } \\
\text { quantitative } \\
\text { study }\end{array}$ & $\begin{array}{l}\text { Nursing students were } \\
\text { unable to determine the } \\
\text { causes of periodontal } \\
\text { disease, but their general } \\
\text { knowledge was } \\
\text { adequate regarding } \\
\text { issues related to } \\
\text { periodontal disease. Most } \\
\text { participants indicated a } \\
\text { lack of confidence in oral } \\
\text { health care practice and } \\
\text { recommended including } \\
\text { more oral health content } \\
\text { in the nursing } \\
\text { curriculum. }\end{array}$ & $\begin{array}{l}\text { A small sample size and } \\
\text { data were collected from } \\
\text { campuses belonging to } \\
\text { the same university, so } \\
\text { results cannot be } \\
\text { generalised. }\end{array}$ \\
\hline $\begin{array}{l}\text { Grant et al., } \\
2011[46]\end{array}$ & $\begin{array}{l}\text { George Brown } \\
\text { College (GBC) } \\
\text { dental clinic, } \\
\text { Ontario, Canada }\end{array}$ & $\begin{array}{l}\text { To report the lessons } \\
\text { learned from the } \\
\text { Interprofessional } \\
\text { education (IPE) initiative } \\
\text { between dental hygiene } \\
\text { and BSCN students and } \\
\text { identify future directions. }\end{array}$ & $\begin{array}{l}\text { Eight 2nd year Dental } \\
\text { Hygiene (DH) students } \\
\text { participated in teaching } \\
\text { oral health to } 2001 \mathrm{st} \\
\text { year Bachelor of Science } \\
\text { (BScN) nursing students } \\
\text { and, } 15 \text { 2nd year BScN } \\
\text { students participated in } \\
\text { teaching blood pressure } \\
\text { measurement to each of } \\
4 \text { pairs of DH students. }\end{array}$ & $\begin{array}{l}\text { Quasi- } \\
\text { experimental } \\
\text { post-survey pilot } \\
\text { study }\end{array}$ & $\begin{array}{l}\text { Both student groups } \\
\text { enjoyed working with } \\
\text { each other and sharing } \\
\text { skill sets. Students } \\
\text { experienced each other's } \\
\text { professional language, } \\
\text { which is an essential step } \\
\text { for good communication } \\
\text { between health } \\
\text { professionals. DH } \\
\text { students found that } \\
\text { BScN students did not } \\
\text { have an adequate } \\
\text { understanding of the } \\
\text { theory of oral health } \\
\text { assessment or daily oral } \\
\text { care. }\end{array}$ & $\begin{array}{l}\text { A pilot study from a } \\
\text { single site so results } \\
\text { cannot be generalised. }\end{array}$ \\
\hline $\begin{array}{l}\text { Czarnecki, } \\
\text { Kloostra, } \\
\text { Boynton, \& } \\
\text { Inglehart, } 2014 \text { [47] }\end{array}$ & $\begin{array}{l}\text { Pediatric } \\
\text { dentistry } \\
\text { clinic, USA }\end{array}$ & $\begin{array}{l}\text { To evaluate } \\
\text { interprofessional } \\
\text { education among } \\
\text { nursing and dental } \\
\text { students, and pediatric } \\
\text { dentistry residents. }\end{array}$ & $\begin{array}{l}\text { Experimental group: Data } \\
\text { collected from } 33 \text { 1st } \\
\text { year nursing students, } 40 \\
\text { 3rd year dental students, } \\
\text { and six pediatric } \\
\text { dentistry residents. } \\
\text { Control group: Data } \\
\text { collected from 1st and } \\
\text { 2nd-year dental students } \\
\text { at the beginning and } \\
\text { end of the term. }\end{array}$ & $\begin{array}{l}\text { Quasi- } \\
\text { experimental } \\
\text { pre- and post- } \\
\text { test survey }\end{array}$ & $\begin{array}{l}\text { Nursing students showed } \\
\text { significant improvement } \\
(p<0.05-0.001) \text { in their } \\
\text { oral health behaviour, } \\
\text { knowledge, and attitudes } \\
\text { regarding the } \\
\text { importance of oral care } \\
\text { and translating theory } \\
\text { into nursing practice. } \\
\text { Dental students also } \\
\text { improved their attitudes } \\
\text { toward the importance } \\
\text { of nurses' engagement } \\
\text { in oral health assessment } \\
\text { and promotion. All } \\
\text { students agreed that } \\
\text { interprofessional clinical } \\
\text { placements are a better } \\
\text { way of learning than } \\
\text { only lectures. }\end{array}$ & $\begin{array}{l}\text { Results based on a } \\
\text { sample from one } \\
\text { university only. No } \\
\text { control group among } \\
\text { nursing students. }\end{array}$ \\
\hline $\begin{array}{l}\text { Farokhi, Muck, } \\
\text { Lozano-Pineda, } \\
\text { Boone, \& } \\
\text { Worabo, } \\
2018 \text { [48] }\end{array}$ & $\begin{array}{l}\text { Church-based } \\
\text { clinic run in } \\
\text { partnership with } \\
\text { San Antonio } \\
\text { Refugee Health } \\
\text { Clinic and } \\
\text { University of } \\
\text { Texas Health San } \\
\text { Antonio, USA }\end{array}$ & $\begin{array}{l}\text { To assess the oral health } \\
\text { literacy and knowledge } \\
\text { gained by patients, } \\
\text { community members, } \\
\text { medical and nursing } \\
\text { students after } \\
\text { participating in an } \\
\text { IPE activity. }\end{array}$ & $\begin{array}{l}\text { Convenience sampling of } \\
\text { nursing students (34), } \\
\text { medical students (38), } \\
\text { community members/ } \\
\text { parish (17), refugee } \\
\text { patients (151) }\end{array}$ & $\begin{array}{l}\text { Quasi- } \\
\text { experimental } \\
\text { pre- and post- } \\
\text { survey }\end{array}$ & $\begin{array}{l}\text { Ten dental, two dental } \\
\text { hygiene, ten medical, } \\
\text { and ten nursing students } \\
\text { operated the clinic every } \\
\text { week. Pre- and post- } \\
\text { survey scores ( } p<0.0001) \\
\text { showed that IPE } \\
\text { benefitted all participants } \\
\text { as measured by } \\
\text { increased oral health } \\
\text { literacy scores among all } \\
\text { groups. The program } \\
\text { provided patient }\end{array}$ & $\begin{array}{l}\text { Convenience sampling } \\
\text { from a single area. }\end{array}$ \\
\hline
\end{tabular}


Table 1 Characteristics of identified studies (Continued)

\begin{tabular}{llll}
\hline Reference & $\begin{array}{l}\text { Setting and } \\
\text { country }\end{array}$ & Objective & Participants \\
\hline & & & \\
& & & \\
& & & \\
University and & To test if oral health & Bachelor of Nursing \\
Whiting, \& & resources designed for & $(n=41)$, Diploma of \\
Donnelly, & workforce training were & Nursing ( $n=66)$ and \\
2018 [49] & sectors, Australia & $\begin{array}{l}\text { relevant to entry-level } \\
\text { nursing or age care }\end{array}$ & $\begin{array}{l}\text { Certificate in Aged Care } \\
\text { course students }(n=17) \\
\text { and educators (6); two }\end{array}$ \\
& qualifications. & educators from each \\
& & & course
\end{tabular}

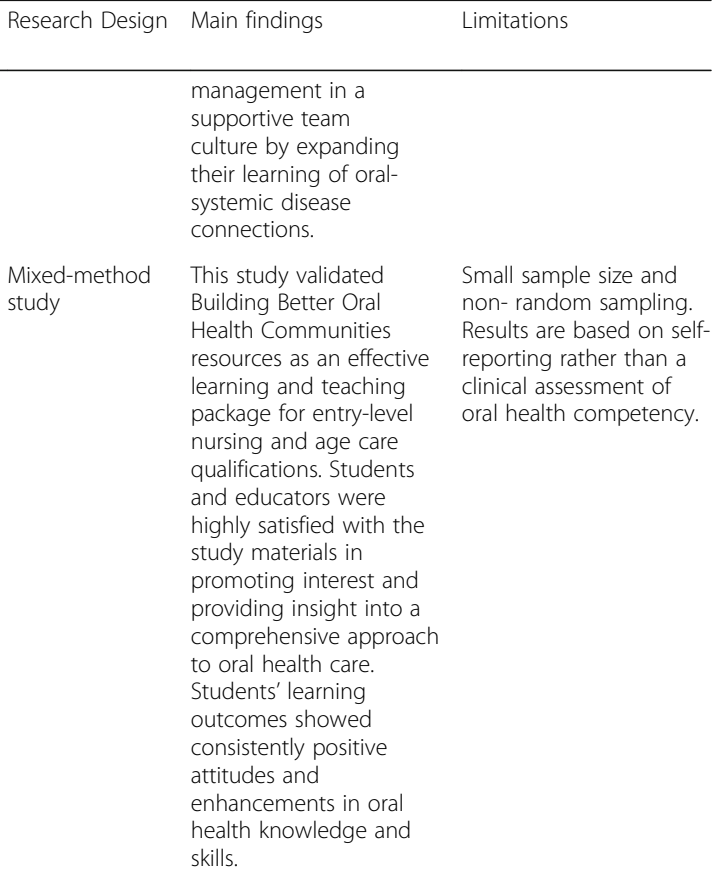

Mixed-method This study validated study Building Better Oral Health Communities resources as an effective learning and teaching package for entry-leve nursing and age care qualifications. Students and educators were highly satisfied with the study materials in promoting interest and providing insight into a comprehensive approach to oral health care. Students' learning outcomes showed consistently positive attitudes and enhancements in oral health knowledge and skills.

Small sample size and non- random sampling. Results are based on selfreporting rather than a clinical assessment of oral health competency.

$\begin{array}{lll}\text { Nierenberg } & \text { School } & \text { To assess dental and } \\ \text { et al., 2018 [50] } & \text { gymnasium, } & \text { nursing students' } \\ & \text { Appalachia, USA } & \text { reflections on an } \\ \text { inter-professional } \\ \text { service-learning } \\ \text { experience in } \\ \\ & \text { Appalachia. }\end{array}$

36 dental and nursing students from University at Buffalo, NY, USA. Of 31 participants who completed the demographic questions, 21 dental students were in the third year, and ten baccalaureate nursing students were seniors (4th year).

Cross-sectional qualitative study 'udents' exposure to rural patients who often lack dental care and have severe oral health problems impacted 'their' appreciation of interprofessional practice and their willingness to provide care in underserved settings. IPE
No control group and results collected from one single site.

$\begin{array}{lll}\text { Coan et al., 2019[51] } & \text { Two local } & \text { To implement and } \\ \text { hospitals with } & \text { evaluate a collaborative } \\ \text { the dedicated } & \text { event with patients to } \\ \text { educational unit, } & \text { help develop dental } \\ \text { Indiana, USA } & \begin{array}{l}\text { hygiene and nursing } \\ \text { students inter- } \\ \end{array} & \text { professional competence }\end{array}$

24 dental hygiene and 25 nursing students at the University of Southern Indiana facilitated care through teamwork, with students gaining mutual respect, confidence, and an increased understanding of the relationship between oral and overall health. Underserved communities benefit tremendously from interprofessional clinical practice as they can consult with multiple providers at one place on the same day.

Retrospective pre-post survey design

5 out of 24 dental hygiene and all 25 nursing students completed the Interprofessional Collaborative Competency Attainment Survey (ICCAS). Results showed significant improvement from pretest to post-test for nursing students (85\% of items on ICCAS with $p \leq 0.004-0.0001$ ) and dental hygiene students (75\% of items on ICCAS). Therefore, structured interprofessional collaborative practice in hospital settings
Small sample size and retrospective survey, which causes the risk of recall bias. 
Table 1 Characteristics of identified studies (Continued)

\begin{tabular}{|c|c|c|c|c|c|c|}
\hline Reference & $\begin{array}{l}\text { Setting and } \\
\text { country }\end{array}$ & Objective & Participants & Research Design & Main findings & Limitations \\
\hline & & & & & $\begin{array}{l}\text { showed a positive effect } \\
\text { in developing } \\
\text { interprofessional } \\
\text { competencies among } \\
\text { nursing and dental } \\
\text { hygiene students. The } \\
\text { collaborative practice } \\
\text { helped students from } \\
\text { both professions to } \\
\text { consider patients' oral } \\
\text { health needs and } \\
\text { implications of improved } \\
\text { oral health for patients' } \\
\text { overall systemic health. }\end{array}$ & \\
\hline $\begin{array}{l}\text { Dsouza et al., } \\
2019 \text { [52] }\end{array}$ & $\begin{array}{l}\text { University of } \\
\text { North Carolina } \\
\text { at Chapel Hill, } \\
\text { USA }\end{array}$ & $\begin{array}{l}\text { To evaluate the influence } \\
\text { of an educational } \\
\text { intervention on } \\
\text { knowledge, confidence, } \\
\text { practice behaviours, and } \\
\text { perceived barriers of } \\
\text { nursing students } \\
\text { regarding preventive } \\
\text { oral health services. }\end{array}$ & $\begin{array}{l}64 \text { first-year Accelerated } \\
\text { Bachelor of Nursing } \\
\text { students }\end{array}$ & $\begin{array}{l}\text { Quasi- } \\
\text { experimental } \\
\text { pre-post survey } \\
\text { design }\end{array}$ & $\begin{array}{l}\text { Pre-survey results } \\
\text { indicated that } 77 \% \text { ( } n= \\
\text { 33) of first-semester } \\
\text { accelerated Bachelor of } \\
\text { Nursing students had a } \\
\text { poor or very poor level } \\
\text { of oral health education. } \\
\text { Only } 7 \% \text { of students } \\
\text { reported that they were } \\
\text { providing oral } \\
\text { counselling and referrals } \\
\text { before the intervention. } \\
\text { The post-survey } \\
\text { questions showed } \\
\text { improvement in oral } \\
\text { health knowledge scores } \\
\text { and confidence in oral } \\
\text { screening and } \\
\text { counselling. A significant } \\
\text { increase was noticed in } \\
\text { the willingness to } \\
\text { implement oral health } \\
\text { services during clinical } \\
\text { visits ( } p<0.0001 \text { ). Post } \\
\text { survey qualitative data } \\
\text { also documented the } \\
\text { benefits of hands-on } \\
\text { learning experiences } \\
\text { with oral screening, } \\
\text { counselling, fluoride } \\
\text { varnish application, and } \\
\text { referrals. Students found } \\
\text { learning from dental } \\
\text { hygiene educators useful. }\end{array}$ & $\begin{array}{l}\text { Small sample size from a } \\
\text { single nursing school } \\
\text { and the absence of a } \\
\text { control group }\end{array}$ \\
\hline
\end{tabular}

\section{Data synthesis}

Extracted data were analysed thematically to produce a narrative description of the findings. While thematic synthesis is commonly used for qualitative research outcomes, it can be used for quantitative research outcomes when there is heterogeneity in measurements. Therefore, the process of thematic synthesis was chosen to narrate the findings of this review [53]. The thematic analysis was conducted according to Braun and Clarke's guidelines: familiarisation with the data, coding, developing potential themes, reviewing themes, defining themes and reporting data relating to research questions [54]. The coding process involved segmenting data into similar groups and identifying the relationship between codes. After finishing the coding process, codes were grouped into descriptive themes that captured similarities in the data across identified studies. Finally, selected themes were reviewed, and synthesised data were finalised in relation to the research questions.

A meta-analyses of the identified studies was not possible because of the small number of studies, participants, and heterogeneity.

\section{Quality assessment}

The quality assessment of the identified studies was done by two authors (VB, $\mathrm{HH})$ using the Mixed Methods Appraisal Tool (MMAT) [55]. All studies were screened regarding the clarity of their research questions, and whether collected data addressed the research questions. Studies that passed the screening were then appraised using methodological quality assessment questions relative to the study design. Studies that met all assessment criteria scored 1; studies that met fewer criteria scored less than 1. 


\section{Results}

Study selection

From a pool of 567 articles, 11 met the eligibility criteria (Fig. 2). A large number of articles were excluded based on the wording of their titles (482), 49 were excluded from reading the abstract, and a further 25 were excluded after reading the full text. Finally, 11 studies were included in this paper. Of the 11 studies, six were conducted in the United States, two in Australia, and one each in Japan, Turkey, and Canada. Studies evaluating nursing students' oral health knowledge and attitudes of oral health care used cross-sectional survey design; intervention studies assessing the impact of the inclusion of oral health components in nursing curricula used quasiexperimental pre-post survey design, post-survey design, retrospective pre-post survey design, and cross-sectional qualitative design. The study evaluating oral health care resources for older people used a mixed-method design.

The main findings of the 11 identified studies were 1.) nursing students' limited oral health knowledge; 2.) their varying attitudes towards providing oral health care; 3 .) the need for further oral health education in nursing curricula; 4.) available learning resources to promote oral health; and 5.) the value of an interprofessional education (IPE) approach to promote oral health care in nursing programs. The results of the quality assessment of the identified papers are shown in Tables 2, 3, 4 and 5.

\section{Synthesis of results: five identified themes Limited knowledge of oral health care among nursing students}

Only three studies [31, 43, 45] assessed the oral health knowledge of nursing students. Using convenience samples ranging from 30 to163 students, each study used different questionnaires. Data were collected from students belonging to a single university or at different campuses of the same university. Studies conducted in the US and Japan showed students had limited oral health care knowledge and inadequate understanding of the crucial elements of an oral health assessment and promotion of effective oral health practices [43, 45]. Only $25 \%$ of all participants in the US-based study by Clemmens et al. [43] were able to recognise the critical components of oral health assessment, despite a majority of students thinking they understood these components. In Japan, Haresaku et al. [45] found that only half of the nursing students knew that oral health diseases could have an impact on systemic health. An earlier study by Pai et al. [31] in Australia showed nursing students understood issues related to periodontal diseases; however, the majority of participants were not confident about their understanding and recommended including more detailed oral health content in their nursing curriculum.

\section{Varying attitudes of nursing students towards oral health care}

Three studies conducted in the US [43], Japan [45], and Turkey [44] evaluated the attitudes of nursing students towards providing oral health care. Clemmens et al. [43] found that nursing students felt oral health care to be an essential component for effective nursing practice. A different trend was observed in nursing students from Turkey and Japan. Nursing students from Turkey often avoided going to a dentist until they developed a painful oral condition [44]. In Japan, the attitudes of nursing students toward oral health appeared negative, with $39.2 \%$ of students stating that they were not interested in learning about oral health and practice [45].

\section{Need for further oral health care education for nursing students}

Seven of the 11 studies provided suggestions for including an oral health component in nursing curricula. Six of the seven studies [46-48, 50-52] focussed on an interprofessional oral health education model. The remaining study [49] provided information about resources for older people's oral health care for nursing curricula.

\section{Available learning resources for nursing students to promote oral health}

Lewis et al. [49] evaluated the relevance of "Building Better Oral Health Communities" (BBOHC) resources for students undertaking a Bachelor of Nursing, Diploma of Nursing, or Certificate III in Aged Care. The $\mathrm{BBOHC}$ resources were developed as a part of the Australian government-funded project for aged care workforce training in older people's oral health care [13]. The BBOHC consists of five modules: 1) better oral health care, 2) dementia and oral care, 3) understanding the mouth, 4) care for natural teeth, and 5) care for dentures. Participating students were highly satisfied with the content of this resource [49]. Student learning outcomes showed consistently positive attitudes and substantial enhancements in oral health care knowledge and skills. Educators found the BBOHC content highly relevant in reinforcing a comprehensive approach to older people's oral health care, which included learning about the consequences of poor health, dry mouth problems, oral health assessment, oral health planning, and timely referral. Educators also found the resources useful in building students' skills in daily oral hygiene practice by increasing awareness about oral hygiene products, tooth brushing techniques, denture cleaning, and techniques to manage care resistive behaviours [49]. 


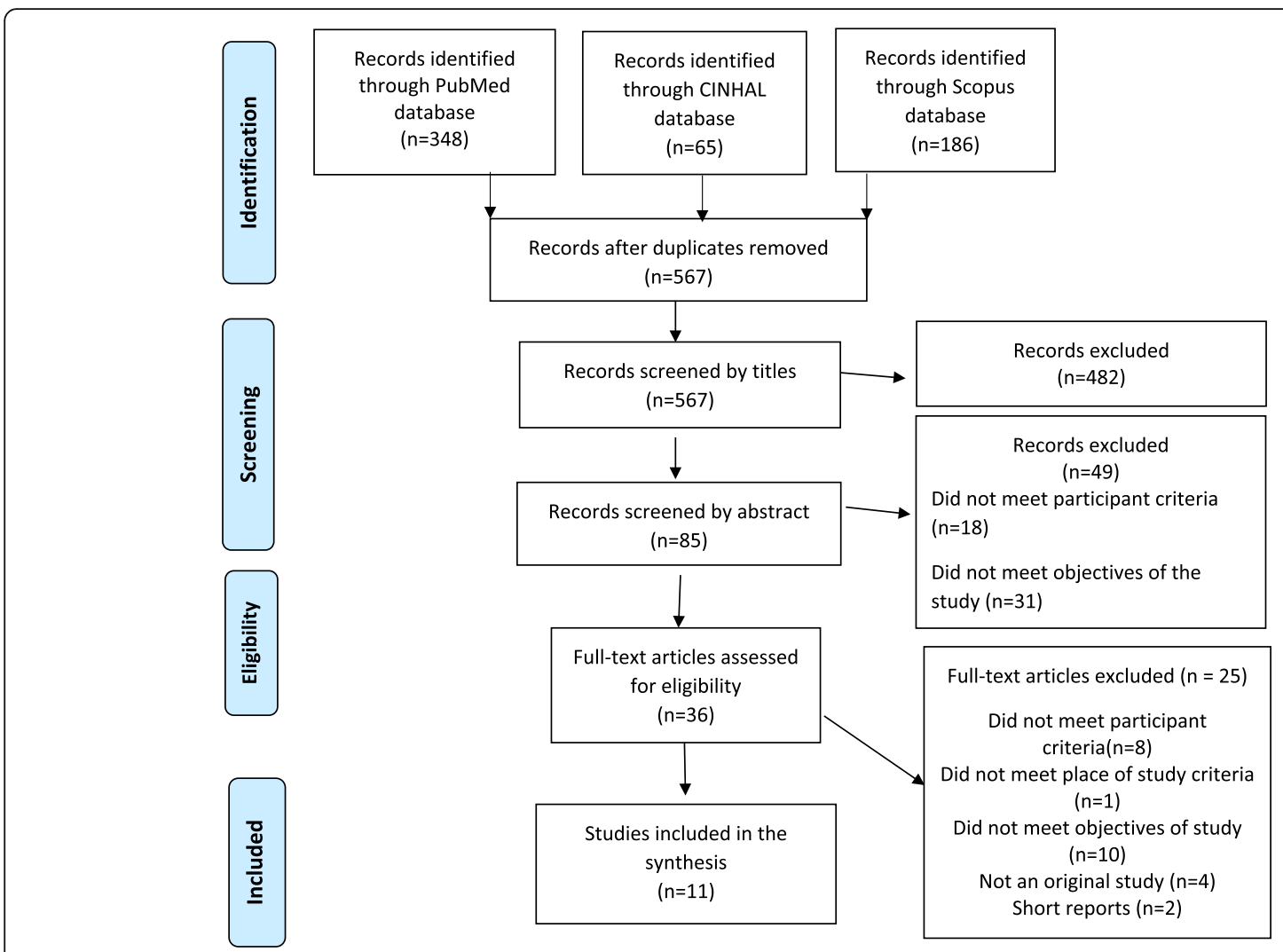

Fig. 2 PRISMA flowchart detailing search results and the selection of studies

\section{Value of an Interprofessional education model}

An interprofessional education (IPE) model in which nursing students work with, learn from, and contribute to the oral-systemic knowledge of dental and other allied health students has been found effective in improving understanding of nursing students towards their role in oral health care [46-48, 50-52]. All the studies focussing on IPE were conducted in the US except the study by Grant et al. [46], which was conducted in Canada.
As a result of their IPE experiences in lectures and simulation exercises, nursing students showed significant improvement in oral health behaviour, knowledge, and attitudes regarding the importance of oral health care [47, 52]. Interprofessional education and practice experiences also increased nursing students' confidence in conducting oral examinations and providing counselling [50]. IPE provided the platform for students to explore oral-systemic disease connections in a supportive team culture $[46,48,51]$. IPE

Table 2 Quantitative descriptive critical review analysis of four identified studies

\begin{tabular}{|c|c|c|c|c|}
\hline $\begin{array}{l}\text { Critical Appraisal Checklist } \\
\text { Quantitative Descriptive }\end{array}$ & $\begin{array}{l}\text { Clemmens } \\
\text { et al., 2012[43] }\end{array}$ & $\begin{array}{l}\text { Dogan, } \\
2013[44]\end{array}$ & $\begin{array}{l}\text { Haresaku et al., } \\
2018[45]\end{array}$ & $\begin{array}{l}\text { Pai et al., } \\
2016[31]\end{array}$ \\
\hline Screening question (SQ)1. Are there clear research questions? & Yes & Yes & Yes & Yes \\
\hline SQ 2. Does the collected data address the research questions? & Yes & Yes & Yes & Yes \\
\hline 1. Is the sampling strategy relevant to address the research question(s)? & Yes & Yes & Yes & Yes \\
\hline 2. Is the sample representative of the target population? & No & No & No & No \\
\hline $\begin{array}{l}\text { 3. Are the measurements appropriate (clear origin or validity is known } \\
\text { or standard instrument)? }\end{array}$ & No & Yes & Yes & Unclear \\
\hline 4. Is the risk of nonresponse bias low? & Yes & Yes & Yes & No \\
\hline 5. Is the statistical analysis appropriate to answer the research question(s)? & Yes & Yes & Yes & Yes \\
\hline Overall quality score* & 0.6 & 0.8 & 0.8 & 0.4 \\
\hline
\end{tabular}

*Overall quality score: Studies met all assessment criteria scored one and studies met fewer criteria scored less than one 
Table 3 Quantitative critical review analysis of four identified studies

\begin{tabular}{|c|c|c|c|c|c|}
\hline $\begin{array}{l}\text { Critical Appraisal Checklist } \\
\text { Quantitative non-randomised study }\end{array}$ & $\begin{array}{l}\text { Czarnecki } \\
\text { et al., } 2014 \text { [47] }\end{array}$ & $\begin{array}{l}\text { Farokhi } \\
\text { et al., } 2018 \\
{[48]}\end{array}$ & $\begin{array}{l}\text { Dsouza et al., } \\
2019[52]\end{array}$ & $\begin{array}{l}\text { Coan et al., } \\
2019 \text { [51] }\end{array}$ & $\begin{array}{l}\text { Grant et al. } \\
2011[46]\end{array}$ \\
\hline SQ1.Are there clear research questions? & Yes & Yes & Yes & Yes & No \\
\hline SQ2.Do the collected data allow one to address the research questions? & Yes & Yes & Yes & Yes & $--^{* *}$ \\
\hline 1. Are the participants representative of the target population? & Yes & No & Yes & No & $--^{* *}$ \\
\hline $\begin{array}{l}\text { 2. Are measurements appropriate regarding both the outcome and intervention } \\
\text { (or exposure)? }\end{array}$ & Yes & Yes & Yes & Yes & $--^{* *}$ \\
\hline 3. Are there complete outcome data? & Yes & Yes & Yes & Yes & $--^{* *}$ \\
\hline 4. Are confounders accounted for in the design and analysis? & Yes & No & Yes & Yes & $-* *$ \\
\hline $\begin{array}{l}\text { 5. During the study period, is the intervention administered (or exposure occurred) } \\
\text { as intended? }\end{array}$ & Yes & Yes & Yes & Yes & $-* *$ \\
\hline Overall quality score* & 1.0 & 0.6 & 1.0 & 0.8 & $-* *$ \\
\hline
\end{tabular}

*Overall quality score: Studies met all assessment criteria scored one and studies met fewer criteria scored less than one

**According to MMAT, further appraisal may not be feasible or appropriate when answer is " $N o$ ' or 'Cannot 'tell' to screening question 1 or 2

helped nursing students to learn oral risk assessments, identify common oral pathologies, engage in oral hygiene activities, use fluoride varnish and work with students from other professions to promote oral health [47]. IPE clinical experiences focussing on oral-systemic health were valuable in enhancing shared professional skills with hands-on care, facilitating effective communication, and working as a team to develop an integrated plan of care to ensure holistic care [50, 51]. Nursing students' experiences in interprofessional clinical practice were instrumental in understanding how underserved and rural communities could benefit from accessing multiple providers at one place on the same day [50].

\section{Discussion}

\section{Summary of evidence}

This review of 11 identified studies documented limited oral health knowledge and varying attitudes (both

Table 4 Qualitative critical review analysis of Nierenberg et al., 2018 [50]

\section{Critical appraisal checklist}

Qualitative study

SQ 1. Are there clear research questions?

SQ 2. Do the collected data allow one to address the research questions?

1. Is the qualitative approach appropriate to answer the research Yes question(s)?

2.Are the qualitative data collection methods adequate to address Yes the research question(s)?

3.Are the findings adequately derived from the data?

4.Is the interpretation of results sufficiently substantiated by data? Yes

5. Is there coherence between qualitative data sources, collection, Yes analysis and interpretation?

Overall quality score*

*Overall quality score: Studies met all assessment criteria scored one and studies met fewer criteria scored less than one favourable and unfavourable) of nursing students towards oral health care. The review identified available learning resources and highlighted the importance of an interprofessional education and practice approach in improving oral health knowledge and attitudes among nursing students.

Growing evidence of the relationship between poor oral health and general systemic health requires urgent attention. The inclusion of oral health care education in nursing curricula, integrated with an interprofessional approach, will strengthen the capability and interest of future nurse practitioners to include evidence-based effective oral health care in routine nursing care. It is important to understand that "oral health care" can be interpreted differently by different health professionals [56]. For nursing practice, oral health care includes

Table 5 Mixed method critical review analysis of Lewis et al., 2018 [49]

Critical appraisal checklist

Mixed method study

SQ1. Are there clear research questions? Yes

SQ2. Do the collected data allow one to address the research Yes questions?

1. Is there an adequate rationale for using a mixed-method design Yes to address the research questions?

2. Are the different components of the study effectively integrated Yes to answer the research question(s)?

3. Are the outputs of the integration of qualitative and quantitative Yes components adequately interpreted?

4. Are divergences and inconsistencies between qualitative and Yes quantitative results adequately addressed?

5. Do the different components of the study adhere to the quality Yes criteria of each tradition of the methods involved?

Overall quality score*

1.0

*Overall quality score: Studies met all assessment criteria scored one and studies met fewer criteria scored less than one 
collaboration with dental, medical, and allied health professionals. For nursing students, this entails understanding the factors affecting people's oral health and oral health-related quality of life, ensuring daily oral care practice, and being able to complete an oral health screening. Such screening includes checking the status and function of oral structures and dentures, swallowing ability, nutritional status, asking each person's perspective about their oral and general health and whether they have any concerns, and making appropriate referrals. Daily oral care for older people in residential care includes assisting with evidence-based oral hygiene, use of saliva substitutes when appropriate, water hydration, desensitising agents, lip balms, denture cleaning tablets, pastes and adhesive pastes, and fluoride varnishes.

Older people are at particular risk for poor oral health. This review showed a significant gap in the current literature on nursing students' knowledge of oral health care for older people and how this gap is best addressed through interprofessional education and practice. Interprofessional education and practice is one of the best ways to improve both nursing students' awareness of the importance of oral health and their role in improving access to and providing oral health services [48, 57]. IPE facilitates collaborative work in varying health care settings including educational institutes [52], dental health clinics [47], mobile clinics in underserved areas [48] and hospitals [51]. While challenges remain in coordinating curricula across disciplines to facilitate students' involvement in IPE initiatives, providing nursing students with opportunities to include oral health assessments in their assessment of overall body function would significantly improve the health outcomes of older people [32, 58]. IPE models have been implemented successfully in many graduate nursing programs in addition to undergraduate nursing programs [46, 59-63]. The "Smile for Life-National Oral Health Curriculum" has been popular with graduate nursing students [17, 59, 62-64]. This comprehensive oral health curriculum was initially developed in 2005 for primary health workers. It is freely available online and could be readily integrated into IPE activities in nursing curricula (www. smilesforlifeoralhealth.com) [65].

Implementing IPE into nursing curricula requires thought, time, and careful planning to ensure that students from other health-related programs can participate $[46,63,66]$. Organising IPE with students and faculty from different health programs with different health knowledge makes IPE challenging [48]. Flexibility, willingness, and cooperation among all professionals are needed for effective collaborative and interprofessional learning [46]. Establishing academic credit for students participating in IPE is an effective way to involve and encourage students in collaborative learning about oral health $[46,66]$.
Effective oral health education must include clinical practice and ideally interprofessional clinical practice. The best way to translate oral health learning to practice is to shift from the traditional physical assessment approach that is Head, Eyes, Ears, Nose, Throat (HEENT) to the Head, Eyes, Ears, Nose, Oral cavity, and Throat (HEENOT) approach for the assessment, diagnosis, and treatment of oral-systemic health [17]. The HEENOT approach ensures that one does "NOT" leave oral health assessment out of any medical history and physical examination. The success of the HEENOT approach was evidenced by more than 1000 referrals to the Nursing Faculty Practice (NFP) from New York University (NYU) dental clinics between 2008 and 2014. The HEENOT approach resulted in increased care appointments and more than 500 referrals to NYU dental clinics from the NFP [17]. Another collaborative model provided students in nursing, dental hygiene, and health services management with community-based experience providing affordable oral health services and oral health education [67]. Nursing students' involvement in early detection of oral health issues and appropriate, timely referral to a dentist can ensure minimal cost treatment and improve patient-centred care [31].

This systematic review is a valuable initial step in identifying the current knowledge and attitudes of nursing students towards providing oral health care and recognising factors to reinforce their interest in oral health care, particularly for older people [45]. Results have several implications for nursing students, nursing educators, nursing education accreditation authorities, and researchers. Nursing students need to understand the importance of oral health, the relationship of poor oral health to systemic disease, the importance of their competency in oral health practices, and their important role in maintaining the health of older people. Oral health education and practical experience occur best in an interprofessional situation to build confidence, motivation, knowledge, and skills. Nursing educators need to understand and implement an interprofessional approach to oral health education and practice in nursing curricula. Nursing education accreditation authorities need to pay attention to develop guidelines to promote oral health care learning and practice among nursing students who are future health professionals. IPE improves workplace practices and productivity, patient health outcomes, staff morale, patient safety, and enables better access to health care [28]. Ongoing rigorous research is required to understand the extent to which oral health is addressed in nursing curricula in Australia and to evaluate the inclusion and impact of oral health content, delivered through interprofessional education and clinical practice, in undergraduate nursing curricula. 


\section{Limitations}

Most of the reviewed studies were conducted in the United States and had small sample sizes belonging to a single location; therefore, the results cannot be generalised. Some intervention studies had quasi-experimental designs, and there was a lack of blinding of the intervention leading to questions on the trustworthiness of the study results. Self-report questionnaires were used in the identified studies which may be biased by respondent beliefs. The long-term evaluation results of an integrated oral health learning model are still not available to check the effectiveness of IPE in building nursing students' capacity in oral healthcare delivery.

\section{Conclusion}

This review supports the need to integrate oral health education into nursing curricula, ideally through an IPE approach, to increase nursing students' knowledge and ability to provide oral care, particularly to maintain the health of older people, and to interest students in providing effective oral care. There is a need to conduct rigorous well-designed studies about how best to achieve this and measure its success. A future nursing workforce with competence in oral health care will help to improve the oral health and quality of life of all people, especially those who are older and dependent on others for care.

\section{Abbreviations}

CINAHL: Cumulative Index to Nursing and Allied Health Literature; OECD: Organisation of Economic Co-operation and Development; IPE: Interprofessional education; MMAT: Mixed Methods Appraisal Tool; BBOHC: Building Better Oral Health Communities; HEENOT: Head, Eyes, Ears, Nose, Oral cavity, and Throat; NYU: New York University

\section{Acknowledgments}

We would like to thank all the authors of the studies included in this systematic review. Also, we would like to thank the Centre for Rural Health and the University of Tasmania for providing opportunities for the first author to develop her research skills.

We would also like to thank the reviewers of this manuscript for providing valuable feedback to strengthen the manuscript.

\section{Authors' contributions}

All authors made a substantial contribution to this review. All authors together set the protocols for this review. VB performed the data search and retrieval. Titles and abstracts were independently screened by two authors $(\mathrm{VB}, \mathrm{HH})$. VB was involved in data extraction and drafted the manuscript. VB and $\mathrm{HH}$ did the methodological quality assessment of all studies. HH, LC, LG revised the subsequent manuscript drafts for content and structure. All authors have read and approved the final manuscript.

\section{Funding}

The first author is supported by a Department of Health, Rural Health Multidisciplinary Training Program, and the University of Tasmania Research Scholarship for her doctoral studies.

The funding bodies played no part in the design of the study, collection, analysis and, interpretation of data, nor in writing this manuscript.

\section{Availability of data and materials}

All data generated or analysed during this study is included in this article.

Ethics approval and consent to participate

Not applicable.
Consent for publication

Not applicable.

\section{Competing interests}

The authors declare that they have no competing interests.

\section{Author details}

${ }^{1}$ Centre for Rural Health (CRH), E Block, Newnham Campus, University of Tasmania (UTas), Launceston, Australia. ${ }^{2} \mathrm{CRH}$, E block, Newnham Campus, UTas, Launceston, Australia. ${ }^{3} \mathrm{CRH}, \mathrm{ABC}$ Building, 1 Liverpool Street, Hobart, Hobart CBD Campuses, UTas, Hobart, Australia. ${ }^{4}$ Wicking Dementia Research \& Education Centre, Room 421C (Level 4), Medical Science 1, UTas, Hobart, Australia.

Received: 15 March 2020 Accepted: 28 June 2020

Published online: 14 July 2020

\section{References}

1. Glick M, Williams DM, Kleinman DV, Vujicic M, Watt RG, Weyant RJ. A new definition for oral health developed by the FDI World Dental Federation opens the door to a universal definition of oral health. Br Dent J. 2016; 221(12):792-3.

2. Petersen PE. The World Oral Health report 2003: continuous improvement of oral health in the 21st century - the approach of the WHO global Oral Health Programme. Community Dent Oral Epidemiol. 2003;31(SUPPL. 1):3-24.

3. World Health Organisation. Oral Health. 2020 [cited 17 June 2020]. Available from: https://www.who.int/news-room/fact-sheets/detail/oral-health. Accessed 17 June 2020.

4. World Health Organisation. Ageing and Health. 2018 [cited 17 June 2020]. Available from: https://www.who.int/news-room/fact-sheets/detail/ageingand-health. Accessed 17 June 2020.

5. Gil-Montoya JA, Ferreira de Mello AL, Barrios R, Gonzalez-Moles MA, Bravo $M$. Oral health in the elderly patient and its impact on general well-being: a nonsystematic review. Clin Interventions in Aging. 2015; ume 10:461-7.

6. Petersen PE, Kandelman D, Arpin S, Ogawa H. Global oral health of older people--call for public health action. Community Dent Health. 2010;27(4 Suppl 2):257-67.

7. Hopcraft MS. Dental demographics and metrics of oral diseases in the ageing Australian population. Aust Dent J. 2015;60(Suppl 1):2-13.

8. Gutkowski S. The biggest wound: oral health in long-term care residents. Annals of Long Term Care: Clinical Care and Ageing. 2011;19(7):23-5.

9. Kandelman D, Petersen $\mathrm{PE}$, Ueda $\mathrm{H}$. Oral health, general health, and quality of life in older people. Special Care Dentistry. 2008;28(6):224-36.

10. Seymour GJ, Ford PJ, Cullinan MP, Leishman S, Yamazaki K. Relationship between periodontal infections and systemic disease. Clin Microbiol Infection. 2007:13(S4):3-10.

11. Awano S, Ansai T, Soh I, Hamasaki T, Yoshida A, Takehara T, et al. Oral health and mortality risk from pneumonia in the elderly. J Dent Res. 2008; 87(4):334-9

12. El-Solh AA. Association between pneumonia and Oral Care in Nursing Home Residents. Lung. 2011;189(3):173.

13. SA Health. Why oral health care is important for older people. 2020 [cited 17 June 2020] Available from: https://www.sahealth.sa.gov.au/wps/wcm/ connect/public+content/sa+health+internet/clinical+resources/clinical+ programs+and+practice+guidelines/oral+health/oral+health+care+for+ older+people/why+oral+health+care+is+important+for+older+people.

14. Kisely S. No mental Health without Oral Health. Can J Psychiatry. 2016;61(5): 277-82.

15. Kossioni AE, Haito-Bryk J, Maggi S, McKenna G, Petrovic M, RollerWirnsberger RE, et al. An Expert Opinion from the European College of Gerodontology and the European Geriatric Medicine Society: European Policy Recommendations on Oral Health in Older Adults 2018:609.

16. Hearn L, Slack-Smith L. Engaging dental professionals in residential agedcare facilities: staff perspectives regarding access to oral care. Australian J Primary Health. 2016;22(5):445-51.

17. Haber J, Hartnett E, Allen K, Hallas D, Dorsen C, Lange-Kessler J, et al. Putting the mouth back in the head: HEENT to HEENOT. Am J Public Health. 2015;105(3):437-41.

18. Hoang H, Barnett T, Maine G, Crocombe L. Aged care staff's experiences of 'better Oral Health in residential care training': a qualitative study. Contemp Nurse. 2018;54(3):268-83. 
19. Petersen PE, Yamamoto T. Improving the oral health of older people: the approach of the WHO global Oral Health Programme. Community Dent Oral Epidemiol. 2005;33(2):81-92.

20. Thomson W, Ma S. An ageing population poses dental challenges. Singap Dent J. 2014;35C:3-8.

21. Bailey R, Gueldner S, Ledikwe J, Smiciklas-Wright $H$. The oral health of older adults: an interdisciplinary mandate. J Gerontol Nurs. 2005;31(7):11-7.

22. Forsell M, Sjögren P, Kullberg E, Johansson O, Wedel P, Herbst B, et al. Attitudes and perceptions towards oral hygiene tasks among geriatric nursing home staff. Int J Dent Hyg. 2011;9(3):199-203.

23. Gibney JM, Wright FA, D'Souza M, Naganathan V. Improving the oral health of older people in hospital. Australasian J Ageing. 2019;38(1):33-8.

24. Jablonski RA, Kolanowski A, Therrien B, Mahoney EK, Kassab C, Leslie DL. Reducing care-resistant behaviors during oral hygiene in persons with dementia. BMC Oral Health. 2011;11:30.

25. Malkin B. The importance of patients' oral health and nurses'role in assessing and maintaining it. Nurs Times. 2008;105:19-23.

26. Albrecht M. Oral health educational interventions for nursing home staff and residents. Cochrane Database of Systematic Reviews. (9).

27. Wårdh I, Hallberg LR, Berggren U, Andersson L, Sörensen S. Oral health care--a low priority in nursing. In-depth interviews with nursing staff. Scand J Caring Sci. 2000;14(2):137-42.

28. World Health Organisation. Framework for action on interprofessional education and collaborative practice 2010 [cited 17 June 2020]. Available from: https://www.who.int/hrh/resources/framework_action/en/. Accessed 17 June 2020

29. FDI World Dental Federation. Optimal Oral Health through inter-professional education and collaborative practice. 2015 [Available from: https://www. fdiworlddental.org/sites/default/files/media/news/collaborative-practice_ digital.pdf]. Accessed 17 June 2020.

30. Dolce MC. Integrating oral health into professional nursing practice: an interprofessional faculty tool kit. J Professional Nurs. 2014;30(1):63-71.

31. Pai M, Ribot B, Tane H, Murray J. A study of periodontal disease awareness amongst third-year nursing students. Contemporary Nurse. 2016;52(6):686-95.

32. Dolce MC, Haber J, Shelley D. Oral health nursing education and practice program. Nurs Res Pract. 2012;2012:149673.

33. Rohr. Assessment and care of the mouth: An essential nursing activity, especially for debilitated or dying inpatients. HNE handover for nurses and midwives. 2012;5(1):33-4.

34. Young LM, Machado CK, Clark SB. Repurposing with purpose: creating a collaborative learning space to support institutional Interprofessional initiatives. Med Reference Services Quarterly. 2015;34(4):441-50.

35. Hoyles A, Pollard C, Lees S, Glossop D. Nursing students' early exposure to clinical practice: An innovation in curriculum development. Nurse education today. 2000;20:490-8.

36. Grønkjær LL, Nielsen N, Nielsen M, Smedegaard C. Oral health behaviour, knowledge, and attitude among nursing students. J Nurs Educ Practice. 2017;7(8):1-6.

37. Daly B, Smith K. Promoting good dental health in older people: role of the community nurse. Brit J Community Nurs. 2015;20(9):431-6.

38. Hoben M, Kent A, Kobagi N, Huynh KT, Clarke A, Yoon MN. Effective strategies to motivate nursing home residents in oral care and to prevent or reduce responsive behaviors to oral care: a systematic review. PLoS One. 2017;12(6):e0178913.

39. Tetuan T. The role of the nurse in oral health. Kansas Nurse. 2004;79(10):1-2.

40. Moore K. Oral health progress in Kansas. Kansas Nurse. 2004;79(10):8-10.

41. Garry B, Boran S. Promotion of oral health by community nurses. Brit J Community Nurs. 2017;22(10):496-502.

42. Liberati A, Altman DG, Tetzlaff J, Mulrow C, Gøtzsche PC, loannidis JPA, et al. The PRISMA statement for reporting systematic reviews and meta-analyses of studies that evaluate healthcare interventions: explanation and elaboration. BMJ. 2009:339:b2700

43. Clemmens D, Rodriguez K, Leef B. Knowledge, attitudes, and practices of baccalaureate nursing students regarding oral health assessment. J Nurs Educ. 2012;51(9):532-5.

44. Doğan B. Differences in oral health behavior and attitudes between dental and nursing students. J Marmara University Institute of Health Sciences. 2013;3(1):34-40.

45. Haresaku S, Monji M, Miyoshi M, Kubota K, Kuroki M, Aoki H, et al. Factors associated with a positive willingness to practise oral health care in the future amongst oral healthcare and nursing students. Eur J Dental Educ. 2018;22(3):e634-e43.
46. Grant L, McKay LK, Rogers LG, Wiesenthal S, Cherney SL, Betts LA. An interprofessional education initiative between students of Dental Hygiene and Bachelor of Science in Nursing. Can J Dent Hyg. 2011;45(1):36-44.

47. Czarnecki GA, Kloostra SJ, Boynton JR, Inglehart MR. Nursing and dental students' and pediatric dentistry residents' responses to experiences with interprofessional education. J Dent Educ. 2014;78(9):1301-12.

48. Farokhi MR, Muck A, Lozano-Pineda J, Boone SL, Worabo H. Using Interprofessional education to promote Oral Health literacy in a facultystudent collaborative practice. J Dent Educ. 2018;82(10):1091-7.

49. Lewis A, Edwards S, Whiting G, Donnelly F. Evaluating student learning outcomes in oral health knowledge and skills. J Clin Nurs. 2018;27(11-12):2438-49.

50. Nierenberg S, Hughes LP, Warunek M, Gambacorta JE, Dickerson SS, Campbell-Heider N. Nursing and Dental Students' reflections on Interprofessional practice after a service-learning experience in Appalachia. J Dent Educ. 2018;82(5):454-61.

51. Coan LL, Wijesuriya UA, Seibert SA. Collaboration of Dental hygiene and nursing students on hospital units: an Interprofessional education experience. J Dent Educ. 2019;83(6):654-62.

52. Dsouza R, Quinonez R, Hubbell S, Brame J. Promoting oral health in nursing education through interprofessional collaborative practice: a quasiexperimental survey study design. Nurse Educ Today. 2019;82:93-8.

53. Ryan C, Hesselgreaves H, Wu O, Paul J, Dixon-Hughes J, Moss JG. Protocol for a systematic review and thematic synthesis of patient experiences of central venous access devices in anti-cancer treatment. Syst Rev. 2018;7(1):61.

54. Braun V, Clarke V. Using thematic analysis in psychology. Qual Res Psychol. 2006;3(2):77-101.

55. Hong QN, Fàbregues S, Bartlett G, Boardman F, Cargo M, Dagenais P, et al. The Mixed Methods Appraisal Tool (MMAT) version 2018 for information professionals and researchers. Educ Inf. 2018;34:285-91.

56. Koichiro U. Preventing aspiration pneumonia by oral health care. Japan Med Assoc J. 2011;54:39-43.

57. Goldberg LR, Koontz JS, Rogers N, Brickell J. Considering accreditation in gerontology: the importance of interprofessional collaborative competencies to ensure quality health care for older adults. Gerontol Geriatrics Educ. 2012;33(1):95-110.

58. Hein C, Schönwetter DJ, lacopino AM. Inclusion of oral-systemic health in predoctoral/undergraduate curricula of pharmacy, nursing, and medical schools around the world: a preliminary study. J Dent Educ. 2011;75(9):1187-99.

59. Dolce MC, Parker JL, Marshall C, Riedy CA, Simon LE, Barrow J, et al. Expanding collaborative boundaries in nursing education and practice: the nurse practitioner-dentist model for primary care. J Professional Nurs. 2017; 33(6):405-9.

60. Estes KR, Callanan D, Rai N, Plunkett K, Brunson D, Tiwari T. Evaluation of an Interprofessional Oral Health assessment activity in advanced practice nursing education. J Dent Educ. 2018;82(10):1084-90.

61. Golinveaux J, Gerbert B, Cheng J, Duderstadt K, Alkon A, Mullen S, et al. Oral health education for pediatric nurse practitioner students. J Dent Educ. 2013;77(5):581-90.

62. Haber J, Hartnett E, Allen K, Crowe R, Adams J, Bella A, et al. The impact of Oral-systemic Health on advancing Interprofessional education outcomes. J Dent Educ. 2017;81(2):140-8.

63. Nash WA, Hall LA, Lee Ridner S, Hayden D, Mayfield T, Firriolo J, et al. Evaluation of an interprofessional education program for advanced practice nursing and dental students: the oral-systemic health connection. Nurse Educ Today. 2018;66:25-32.

64. Kent KA, Clark CA. Open wide and say A-ha: adding Oral Health content to the nurse practitioner curriculum. Nurs Educ Perspect. 2018;39(4):253-4

65. Clark MB DA MR, Deutchman M, Gonsalves W, Silk H, Wrightson AS, Quinonez R, Dolce M, Dalal M, Rizzolo D, Sievers K. Smiles for Life: A National Oral Health Curriculum. 2010. Available from: https://www. smilesforlifeoralhealth.com.

66. Goldberg LR, Brown GR, Mosack VA, Fletcher PA. Student reflections following exposure to a case-based interprofessional learning experience: preliminary findings. J Interprofessional Care. 2015;29(4):380-2.

67. Duley SI, Fitzpatrick PG, Zornosa X, Barnes WG. A center for oral health promotion: establishing an inter-professional paradigm for dental hygiene, health care management and nursing education. J Dental Hygiene. 2012;86(2):63-70.

\section{Publisher's Note}

Springer Nature remains neutral with regard to jurisdictional claims in published maps and institutional affiliations. 